\title{
Journal of Economic Education and Entrepreneurship
}

UNvesersas

http://e-journal.ivet.ac.id/index.php/jeee

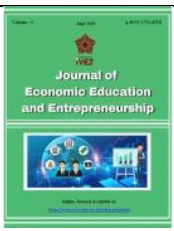

\section{MODERNISASI PENDIDIKAN DI PONDOK PESANTREN MIFTAHUL \\ 'AMAL JIKEN, BLORA \\ Lyly Bayu Aji ${ }^{1}$, Marhaeni Dwi Satyarini ${ }^{2}$}

\author{
Fakultas Keguruan dan Ilmu Pendidikan, Universitas IVET, Indonesia
}

DOI: https://doi.org/10.31331/ieee.v1i1.1219

Info Articles

Sejarah Artikel:

Disubmit 6 Juli 2019

Direvisi 11 Agustus 2019

Disetujui 1 Oktober 2019

Keywords:

Education modernization, pondok pesantren

Pondok pesantren harus mengembangkan dan membuka diri terhadap perubahan yang terjadi di era globalisasi sesuai perkembangan teknologi, agar mampu mensejajarkan diri dengan lembaga pendidikan lainnya. Penelitian ini bertujuan untuk mengetahui latar belakang, tujuan, pelaksanaan dan kendala modernisasi pendidikan di Pondok Pesantren Miftahul 'Amal Blora.Sumber data penelitian ialah Kyai, Ketua pondok pesantren, Ustadz atau guru, dan Santri. Pengumpulan data menggunakan metodeinterview, observasi, dan dokumentasi, dengan teknik analisis deskriptif kualitatif Hasil penelitian menunjukkan: latar belakang modernisasi pendidikan di pondok pesantren meliputi: a) image negatif masyarakat tentang pendidikan pondok pesantren yang kuno dan tertinggal dari perkembangan IPTEK, b) tradisi lama yang jika dipertahankan menyebabkan pondok pesantren tidak diminati masyarakat dan c) pembelajaran hanya mengkaji materi agama yang didasarkan pada kitab kuning. Tujuan modernisasi pondok pesantren adalah : 1) memenuhi kebutuhan santri akan keilmuan, baik ilmu agama dan ilmu pengetahuan umum lainnya dan ketrampilan sesuai dengan perkembangan IPTEK, 2) meningkatkan kualitas dan kemandirian santri dengan menyesuaikan pendidikan di pondok pesantren dalam aspek kurikulum, metode pembelajaran, teknologi, dan ketrampilan, 3) meningkatkan kualitas pendidik dan melengkapi fasilitas pondok sesuai perkembangan teknologi. Pelaksanaan modernisasi pendidikan di pondok pesantren Miftahul 'Amal Jiken, Blora meliputi: modernisasi kelembagaan, kurikulum, metode pembelajaran, kualitas sumber daya manusia, serta melengkapi sarana prasarana pondok dengan fasilitas berbasis teknologi, dan kendalanya antara lain: sulitnya mengubah mind set Kyai sepuh, keterbatasan dana dan kualitas sumber daya manusia.

Abstract

Pondok pesantren must develop and open themselves to changes that occur in globalization era following technological development, to be in the similar position to other educational institutions. This research has its purposes to understand the background, goals, implementation, and obstacles of education modernization in PondokPesantrenMiftahul 'AmalBlora.The source of research data isKyai, Head of PondokPesantren, Ustaz or teacher, and Students. The data collection uses interview, observation, and documentation method with qualitative descriptive analysis technique. The research results show modernization background of education in pondokpesantren: a). society's negative image on education in pondokpesantren that is thought to be old fashioned and left behind in science and technological aspects b). old traditions when it is maintained causepondokpesantren not becoming people's favorite c). learning activities that only study religion subjects based on kitabkuning. The purpose ofpondokpesantren modernization: 1. fulfilling students' need of knowledge, both religion and science also skills as in line with science and technology development, 2. improving students' quality and independence by adapting education in pondokpesantren in curriculum, learning methods, technology, and skills aspects, 3.reinforcing educators' quality and equip pondokpesantren with facilities in corresponding to technology development. The implementation of education modernization in PondokPesantrenMiftahul 'AmalJiken, Blora includes: institution, curriculum, learning methods, human resources quality modernization, and equip pondokpesantren with technological based facilities, and the obstacles cover: difficulties in upgrading old Kyai's mindset, lack of funding and human resources quality. 


\section{PENDAHULUAN}

Lembaga pesantren hidup sejak lama dan telah menjadi bagian dari sistem pendidikan sebagian umat Islam Indonesia yang merupakan golongan mayoritas dan mengalami perubahan dari masa ke masa sesuai perkembangan masyarakat. Hampir di seluruh pelosok nusantara, khususnya dipusat-pusat kerajaan Islam terdapat lembaga pendidikan yang kurang lebih serupa dengan pesantren, meski dengan nama yang berbeda-beda, seperti Maunasah di Aceh, Surau di Minangkabau, dan Pesantren di Jawa.

Pesantren adalah suatu lembaga pendidikan Islam di mana para santrinya tinggal di pondok dipimpin oleh kiai untuk mempelajari, memahami, mendalami, menghayati dan mengamalkan ajaran agama Islam dengan menekankan pentingnya moral keagamaan sebagai pedoman perilakunya dalam kehidupan sehari-hari. (Kompri, 2018:3). Sahal Mahfudz dalam Abdurrahman Mas'ud (2013:27) menyebutkan pondok pesantren adalah lembaga pendidikan Islam yang memiliki unsur Kyai atau Ustadz, masjid sebagai tempat ibadah dan penyelenggaraan pendidikan, pondok sebagai tempat tinggal santri, kitab-kitab Islam sebagai sumber kajian, manajemen, dan pesantren sebagai sebuah sistem.

Menurut Zamakhsyari Dhofier (2011) pesantren terbagi menjadi pesantren salaf dan khalaf. Pesantren salaf adalah lembaga pesantren yang mengajarkan kitab-kitab Islam klasik sebagai inti pendidikan, yang mengajarkan ilmu-ilmu agama saja kepada santrinya tanpa mengenalkan pengajaran pengetahuan umum, dengan metode mengajar sorogan dan bandongan. Pesantren khalaf (modern) adalah lembaga pesantren yang memasukkan pelajaran umum dalam kurikulum yang dikembangkan atau pesantren yang menyelenggarakan dan mendirikan sekolah umum seperti SD/MI, SMP/MTS, SMA/MA, dan bahkan Perguruan Tinggi atau Universitas.

Metode sorogan merupakan metode pembelajaran individual, Abdul Mughits (2008:151) menyebutkan secara bergiliran santri membaca di hadapan kyai atau ustadz, yang melakukan pengecekan penguasaan santri terhadap materi kitab yang sudah dibacakan kyai sebelumnya, santri yang sudah menguasai materi kitab yang dibacanya akan mendapat tambahan materi berikutnya. Metode bandongan sering juga disebut metode halagah termasuk metode pembelajaran klasikal dan monolog, pada metode ini kyai membaca kitab, dan menerjemahkan serta menerangkan isinya menggunakan bahasa daerah setempat, sejumlah santri mendengarkan dan memberi catatan-catatan pada kitab yang dipelajarinya (Armai Arif, 2002: 154).

Tujuan pesantren adalah menciptakan dan mengembangkan kepribadian muslim, sesuai dengan ajaran Islam dan menanamkan rasa keagamaan pada semua segi kehidupan warga negara yang berguna bagi agama, masyarakat dan negara (Qomar, 2005)

Pesantren yang selama ini diidentikkan sebagai lembaga pendidikan tradisional, dengan metode pembelajaran satu arah, Kyai sebagai penguasa utama dalam proses pembelajaran serta sarana-prasarana seadanya yang harus diterima santri sebagai bentuk kesederhanaan hidup dan ketaatan pada ustad, tidak lagi menarik bagi sebagian masyarakat untuk belajar di pesantren. Pemikiran moderat para santri muda serta kesadaran untuk mengembangkan diri dan pondok pesantren sebagai lembaga pendidikan yang modern dan berkualitas, telah mengubah wajah beberapa pondok pesantren menjadi lembaga pendidikan dengan bangunan yang megah, fasilitas modern berbasis teknologi, dengan lulusan yang menguasai bidang keagamaan (Islam) serta ilmu pengetahuan lain dan teknologi, dan mampu bersaing dalam kancah nasional dan internasional.

Keberhasilan beberapa pondok pesantren memodernisasi diri menjadi pilihan baru bagi orang tua sebagai lembaga pendidikan yang diharapkan mampu memberikan keilmuan keagamaan sekaligus keilmuan terbaru yang dibutuhkan dunia usaha dan masyarakat pada umumnya. Kenyataan ini menyebabkan pondok pesantren yang tidak melakukan perbaharuan ditinggalkan oleh para santri.Pesantren modern, berkualitas dengan basis agama, penguasaan keilmuan, berbasis teknologi dan ketrampilan lulusan yang sesuai perkembangan IPTEK dan kebutuhan masyarakat menjadi pilihan para orang tua untuk menyekolahkan anaknya di pesantren tersebut. 
Modernisasi pesantren harus dipahami sebagai perubahan menuju proses dan tujuan yang lebih baik, seperti disarankan dalam Al-Qur'an surat Ar-Ra'd ayat 11 yang artinya: "Sesungguhnya Allah tidak merubah keadaan sesuatu kaum sehingga mereka merubah keadaan yang ada pada diri mereka sendiri". Modernisasi pondok pesantren merupakan suatu keniscayaan, karena kehidupan manusia juga mengalami perubahan sesuai dengan perkembangan budaya, ilmu pengetahuan dan teknologi.

Seperti halnya pondok pesantren lainnya, Pondok Pesantren Miftahul Amal Jiken, Blora juga mengalami pasang surut jumlah santri, dalam proses pendidikan masih menggunakan model pembelajaran lama seperti sorogan dan bandongan atau halaqah. Metode sorogan lebih bersifat pembelajaran individu antara kyai dan santri, dengan mengulang-ulang bacaan kitab yang dipelajari sampai santri betul-betul menguasai kitab tersebut untuk melanjutkan pada materi berikutnya. Metode bandongan atau halaqoh lebih bersifat kelompok, kyai membacakan dan mengulas materi kitab di hadapan santri dalam jumlah yang besar, dan santri menyimak serta memberi tanda dan catatan pada kitab yang dipegangnya. Sementara beberapa pondok pesantren lain telah berhasil mengembangkan diri menjadi pondok pesantren modern dengan tetap mempertahankan ciri khas masing-masing pondok.

Berdasarkan uraian di atas penelitian bertujuan untuk mengetahui latar belakang, tujuan dan pelaksanaan serta kendala modernisasi pendidikan di Pondok Pesantren Miftahul 'Amal Blora.

Menurut Abudin Nata dalam Harapandi Dahri (2007), modern diartikan sebagai yang terbaru atau mutakhir, modernisasi berarti pembaharuan atau tajdid dalam bahasa Arab yaitu usahausaha untuk mengubah pola, paham, institusi, dan adat untuk disesuaikan dengan suasana baru yang ditimbulkan oleh kemajuan ilmu pengetahuan dan teknologi. Abdurrahman Wahid (2001) menyebutkan dalam modernisasi terkandung dinamisasi yaitu penggalakan kembali nilai-nilai hidup positif yang telah ada, mencakup nilai-nilai lama dan nilai-nilai baru yang dianggap lebih sempurna. Modernisasi pendidikan dapat disimpulkan sebagai usaha-usaha menuju ke arah pembaharuan dan penyempurnaan sistem pendidikan untuk menjalankan program dan mencapai tujuan yang lebih baik.

Menurut Soekanto (2017) pelaksanaan modernisasi harus mengandung unsur :

a. Cara berifikir yang ilmiah (scientific thinking), logis (masuk akal) dan berdasarkan fakta empirik yang dapat dipertanggung jawabkan.

b. Mewujudkan sistem birokrasi melalui proses pengelolaan, pelaksanaan, pemeliharaan dan pengendalian yang akuntabel.

c. Adanya sistem pengumpulan data yang sistematis, terpusat, dan mampu memberikan informasi secara cepat dan jelas.

d. Penciptaan iklim yang favourable pada masyarakat atas pelaksanaan modernisasi melalui sosialisasi dengan menggunakan alat-alat komunikasi massa.

e. Membutuhkan organisasi yang kuat, didukung anggota yang memiliki kecerdasan, dedikasi dan kedisiplinan diri tinggi yang sangat dibutuhkan dalam modernisasi.

f. Adanya sentralisasi wewenang dalam perencanaan dan pelaksanaan modernisasi.

Menurut Nurcholis Madjid dalam Yasmadi ( 2002) dunia pendidikan Islam harus memodernisasi diri guna mengejar ketertinggalannya dan untuk memenuhi tuntutan teknologi di masa depan. Menurut Azumardi Azra (2001), modernisasi pesantren mengubah sistem dan pendidikan pesantren. Perubahan yang sangat mendasar terjadi pada aspek-aspek kelembagaan, kurikulum dan metodologi. Khoirzaman (2014) menyebutkan modernisasi pendidikan meliputi modernisasi infrastruktur pendidikan, modernisasi cara mengajar dan cara belajar. Hasil penelitian Abdul Aziz (2014) menunjukkan modernisasi pendidikan pesantren merupakan jawaban pesantren terhadap perubahan zaman dan kebutuhan masyarakat.

Modernisasi pendidikan merupakan pembaharuan dan penyempurnaan sistem pendidikan dalam mewujudkan kegiatan belajar mengajar lebih efektif agar peserta didik dapat mengembangkan potensi dirinya, dengan adanya pendidikan peserta didik dapat memiliki 
pengetahuan, kecerdasan, akhlak mulia, kepribadian, kekuatan spiritual, dan keterampilan yang bermanfaat bagi diri sendiri, masyarakat, bangsa dan negara.

\section{METODE}

Penelitian ini menggunakan pendekatan kualitatif, meneliti obyek pada kondisi alamiah. Peneliti merupakan instrumen kunci, pengambilan sampel sumber data dilakukan secara purposive, antara lain : Pimpinan sekaligus Kyai pondok pesantren Miftahul 'Amal Jiken Blora, Lurah atau Ketua pondok, Ustadz atau guru pengajar, serta dua orang santri yang telah belajar di pondok pesantren lebih dari 1 tahun.

Fokus penelitian adalah: latar belakang, tujuan, pelaksanaan dan kendala modernisasi pendidikan di Pondok Pesantren Miftahul 'Amal Jiken Blora. Pengumpulan data menggunakan metode wawancara, observasi dan dokumentasi, dengan pendekatan trianggulasi. Data terkumpul dianalisis dengan pendekatan induktif kualitatif yang menekankan pada makna data terkumpul untuk dideskripsikan.

\section{HASIL DAN PEMBAHASAN}

Jumlah santri pondok pesantren Miftahul 'Amal tahun 2019 sebanyak 114 santri, terdiri atas 66 santri putra dan 48 santri putri. Terdapat dua (2) jenis santri di Pondok Pesantren ini, yakni : santri mukim dan santri tidak mukim, sebagian besar merupakan santri mukim yang berasal dari luar kota Blora. Santri mukim menginap di asrama pondok pesantren dan bersekolah formal yang terdapat di pondok pesantren seperti MTs SA Kasyiful Amal, MA Miftahul Amal dan SMK AlGhozali. Santri yang tidak mukim bertempat tinggal tidak jauh dari pondok dan hanya ikut mengaji di sore hari, jumlah santri ini per hari sekitar tiga sampai lima orang saja.

Berdasarkan hasil observasi lapangan, diperoleh jadwal kegiatan di Pondok pesantren Miftahul 'Alam, yang disajikan dalam Tabe1.2

Tabel 1.2

Jadwal Kegiatan di Pondok pesantren Miftahul 'Alam

\begin{tabular}{|c|l|l|}
\hline No & \multicolumn{1}{|c|}{ Waktu } & \multicolumn{1}{c|}{ Kegiatan } \\
\hline 1 & $04.00-05.30$ & Jamaah sholat subuh dilanjutkan membaca QS. Al-Waqiah dan Al-Mulk \\
\hline 2 & $05.30-07.00$ & Membersihkan lingkungan pondok dan persiapan sekolah \\
\hline 3 & $07.00-13.30$ & Bersekolah di sekolah formal \\
\hline 4 & $13.30-15.00$ & Jamaah sholat dzuhur, makan siang dan istirahat \\
\hline 5 & $15.00-18.00$ & Jamaah sholah ashar, mengaji Al-Qur'an dan membersihkan diri \\
\hline 6 & $18.0-19.00$ & $\begin{array}{l}\text { Jamaah sholat maghrib dilanjutkan mengaji kitab, dipimpin oleh Kyai dan } \\
\text { Ustadz }\end{array}$ \\
\hline 7 & $19.00-22.00$ & $\begin{array}{l}\text { a. Setiap hari Jum'at s/d Minggu, mengaji kitab Bulughul Maram dan } \\
\text { b. Hari Senin s/d Rabu mengaji kitab tafsir Jalalain } \\
\text { c. Hari Kamis membaca surat Yasin dan Tahlil }\end{array}$ \\
\hline 8 & $22.00-04.00$ & $\begin{array}{l}\text { Jang dilaksanakan setiap hari Jum'at s/d Rabu, dan libur pada hari } \\
\text { Kamis. }\end{array}$ \\
\hline & & Istirahat, tidur malam. \\
\hline
\end{tabular}

\section{Latar Belakang Modernisasi Pendidikan di Pondok Pesantren Miftahul 'Amal Jiken, Blora}

Dalam wawancara dengan sumber utama Pengasuh atau Kyai Pondok Pesantren disebutkan, " Menurut image masyarakat pendidikan di pesantren itu tidak bermutu. Sebenarnya di pesantren itu sangat bermutu, oleh karena itu keluarga pesantren ingin sekali supaya image masyarakat itu hilang dan pesantren menjadi berkualitas secara berkesinambungan, dengan 
demikian nanti ada balancing (keseimbangan) antara pendidikan agama dan pendidikan umum, sehingga santri lulus dari pesantren tidak banyak yang menganggur".

Ketua Pondok pesantren Ahmad Sholeh, S.Pdi menyebutkan, "pondok pesantren perlu mengikuti zaman, seperti halnya Al-Qur'an, bukan masalah zamannya yang mengikuti, tetapi memang Al-Qur'an itu biasa diterapkan untuk zaman sekarang dan yang akan datang. Pondok pesantren harus megikuti perkembangan zaman yang ada, supaya tidak tertinggal dengan pendidikan lainnya"

Berdasarkan hasil wawancara tersebut dapat dijelaskan bahwa latar belakang modernisasi Pondok Pesantren Miftahul 'Alam, antara lain :

a. Sebagian masyarakat beranggapan pendidikan di pesantren kuno, tidak bermutu dan hanya mengajarkan ilmu agama secara konvensional, pesantren ingin menghilangkan image tersebut, oleh karena itu Pondok pesantren harus dikembangkan, di samping mengkaji agama juga mengkaji masalah umum, sehingga ada keseimbangan antara pendidikan agama dan pendidikan umum

b. Untuk mengikuti perkembangan zaman, seperti halnya Al-Qur'an, bukan masalah zamannya yang mengikuti tetapi karena Al-Qur'an bisa diterapkan untuk zaman sekarang maupun zaman yang akan datang. Pondok mengikuti perkembangan zaman yang ada supaya tidak tertinggal dengan pendidikan yang lain.

c. Tradisi lama lama pondok pesantren yang, jika dipertahankan tanpa ada penyesuaian dengan perkembangan ilmu pengetahuan dan teknologi, tidak akan diminati para orang tua dan santri. Perubahan yang dilakukan bukan berarti menghilangkan semua tradisi lama, akan tetapi memperbaiki atau memadukan sesuatu yang sifatnya tradisional dengan sesuatu yang baru, sebagian tradisi lama/konvensional yang dianggap layak tetap dipertahankan, agar para santri menjadikan konven-konven ( tata aturan) positif yang ada di pondok pesantren menjadi kebiasaan santri, selalu dijalankan di pondok dan dalam kehidupan bermasyarakat.

\section{Tujuan Modernisasi Pondok Pesantren Miftaul 'Alam bertujuan :}

Dalam wawancara dengan pengasuh pondok pesantren KH. Dawam Nawawi, disebutkan," tujuan diadakannya modernisasi agar di pesantren tidak hanya diajarkan pendidikan agama, tetapi juga ilmu-ilmu umum, sehingga santri memiliki bekal hidup di dunia dari modal modernisasi ilmu-ilmu umum dan bekal di akherat karena standar keilmuan di pesantren adalah agama"

Ketua pondok pesantren Ahmad Sholeh, S.Pdi menyebutkan, " tujuan modernisasi pondok pesantren ialah untuk mempersiapkan santri tidak hanya menguasai kitab kuning saja, tetapi juga memperbaiki metodenya dan menambah dengan life skills, agar ke depannya santri bisa berbaur dan mengamalkan penguasan ilmu agamanya pada kehidupan yang lebih komplek"

Menurut santriwati Luluk Niken Nihayah, " modernisasi diperlukan agar santri meiliki pengetahuan umum dan ketrampilan tidak hanya ilmu agama Islam saja, tidak ketinggalan zaman dan dapat menguasai teknologi,dan ilmunya daapt diaplikasikan dalam kehidupan bermasyarakat". Santriwati Aliatun Nashikah menambahkan, " agar pondok pesantren pendidikannya lebih modern dan lebih diminati banyak masayarakat".

Dari pendapat nara sumber di atas, modernisasi pondok pesantren menjadi suatu keharusan, tujuan modernisasi perkembangan pondok pesantren akan sejalan dengan perkembangan ilmu pengetahuan umum, teknologi dan kehidupan masyarakat yang semakin komplek, yaitu :

a. Mempersiapkan santri tidak hanya memahami dan menguasai ilmu agama dengan mengkaji kitab kuning saja tetapi juga memahami ilmu pengetahuan umum lain, sehingga mampu memahami makna kitab agama yang dipelajari dikaitkan dengan realitas yang ada, dan pada akhirnya santri mampu menerapkan secara comprehensive makna isi kitab kuning terkait dengan peristiwa dan realitas kehidupan masyarakat. 
b. Santri mendapatkan bekal pengetahuan, sikap dan ketrampilan yang utuh, baik ilmu agama, ilmu-ilmu pengetahuan lain dan teknologi yang terus berkembang, dan mengikuti pelajarannya dengan metode yang lebih modern, menguasai isinya pembelajaran dan life skills-nya. Pondok pesantren harus memanfaatkan perkembangan teknologi untuk kegiatan mengaji dan mempelajari kitab-kitab klasik, agar para santri tidak ketinggalan dalam penguasaan teknologi, sehingga para santri dapat mengimplementasikan dan mengamalkannya penguasaan ilmu agamanya dalam kehidupan masyarakat yang lebih kompleks.

c. Meningkatkan kualitas pendidikan dan ketrampilan: santri, pendidik dan melengkapi fasilitas pondok pesantren sesuai perkembangan teknologi.

\section{Modernisasi Pendidikan di Pondok Pesantren Miftahul 'Amal Jiken, Blora}

Dalam wawancara dengan nara sumber Ketua pondok pesantren, disebutkan, " dahulu pondok hanya mengacu pada Kyai saja dengan beberapa pengurus yang merangkap banyak tugas dan tanggung jawab, sekarang telah dibuat struktur organisasi secara formal, yang meliputi : ketua, sekretaris, bendahara dan dewan-dewan dengan masing-masing job description yang spesifik dan jelas"

Lebih lanjut ustadz Muhammad Muqorrobin menjelaskan, "pembelajaran tidak hanya membaca kitab kuning, tahlil dan yasin, kurikulum yang digunakan perpaduan kurikulum salafiah dan kurikulum modern sesuai standar kurikulum nasional yang dikeluarkan oleh Departemen Agama, serta penambahan mata pelajaran, seperti : pidato empat bahasa, yaitu : bahasa Indonesia, Inggris, Arab, dan Jawa serta penumbuhan karakter intrepreneur dan nasionalisme".

Modernisasi pendidikan di pondok pesantren juga terkait dengan pembaharuan metode pembelajaran, menurut Ustadz Muqorrobin, S.Pdi, " pondok pesantren masih mengadopsi metode pembelajaran sorogan dan bandongan, hafalan dalam membaca kitab kuning, dan dalam era modernisasi juga diaplikasikan sistem takror atau pembelajaran sebaya dari santri senior kepada yuniornya, bertukar pikiran dan diskusi masalah yang up to date untuk menghadapi masalah di sekitar kita".

Modernisasi bidang sumber daya manusia (SDM) menurut Pengasuh pondok pesantren KH. Dawam Nawai, " diperlukan tenaga pendidik pesantren yang memiliki skill dan mentalitas tanggung untuk memajukan pesantren yang modern, harus lebih dulu dilakukan modernisasi terhadap kyai dan ustadznya, melalui pemberian pengalaman dan pelatihan-pelatihan yang diselenggarakan oleh pemerintah". Lebih kanjut Ketua pondok pesantren menyebutkan, “ diperlukan penambahan jumlah ustadz, juga peningkatan kualifikasinya, yang dulu hanya lulusan pondok pesantren sekarang harus melajutkan ke jenjang S1"

Ustadz Muqorrobin, S.Pdi menambahkan, " yang telah kami lakukan dengan cara melaksanakan rapat kerja secara rutin, tiap tiga bulan sekali untuk menyamakan persepsi serta menyusun rencana kerja, melaksanakan studi banding 'ngudi kwaruh' ke pondok pesntren Gontor dan Tebu Ireng"

Modernisasi sarana prasarana digital menjadi tantangan tersendiri terkait dengan ketersediaan dana, meskipun sarana fisik sudah memadai, menurut Ketua pondok pesantren Ahmad Sholeh, S.Pdi, "sarana sangat memadai karena sudah tersedia ruang pembelajaran, kamar tidur, kamar mandi, masjid, aula, ruang kelas, dan sedang dikembangkan taman baca dan laboratorium computer". Menurut santriwati yang diwawancarai," kekurangan pesantren ini pada teknologi digital dalam pembelajaran yang belum memadai, sedangkan kelebihannya ada ponok torikohnya, pondok sekolahnya, pondok bagi orang berkebutuhan khusus dan pondok wirausaha".

Berdasarkan hasil wawancara dan observasi fasilitas pondok pesantren, dapat dideskripsikan bahwa : modernisasi pendidikan yang dilaksanakan Pondok Pesantren Miftahul 
'Alam, meliputi modernisasi : kelembagaan (organisasi), kurikulum, metode pembelajaran, sumber daya manusia yang meliputi ustad/ustadzah dan para pengasuh dan fasilitas (saranaprasarana), juga mendirikan sekolah-sekolah umum yaitu : Mts. Sa. Kasyiful 'Amal, MA. Miftahul 'Amal dan SMK Al-Ghozali

a. Modernisasi kelembagaan/organisasi,

Kepengurusan yang dulunya tersentralisasi pada Kyai sebagai penanggung jawab sekaligus sebagai pimpinan, pendidik dan pengasuh, dan Nyai sebagai sekretaris, sekaligus sebagai bendahara, pendidik dan pengasuh, dan para ustadz yang merangkap tanggung jawab sebagai pendidik, pengasuh, keamanan pondok pesantren dan berbagai tugas lainnya. Untuk saat ini kelembagaan pondok pesantren Miftahul 'Amal sudah disusun dalam suatu struktur organisasi dengan pendekatan desentralisasi pembagian tugas dalam kepengurusan yang meliputi : Penasehat, Penanggung jawab, Ketua, Sekretaris, Bendahara, Seksi Pendidikan, Seksi Usaha, Seksi Ketrampilan, Seksi Kesehatan, dan unsur pelaksana teknis yang terdiri atas : Unsur/kelompok Ustadz/pendidik, Unsur pengasuh/pengawas pondok dan tenaga kebersihan/keamanan lainnya.

b. Modernisasi Kurikulum.

Seperti pondok pesantren salaf lainnya, pondok Pesantren Miftahul 'Amal semula hanya mempelajari kitab-kitab klasik yang menjadi ciri khas pembelajaran didalam pesantren salaf, dengan materi : fiqih, nahwu, shorof, tafsir, tasawwuf dan kitab ahkam, hafalan Al-Qur'an dan lainnya, yang disampaikan menggunakan metode klasik seperti halaqoh, sorogan, dan bandongan. Modernisasi kurikulum dilaksanakan dengan menambahkan pembelajaran Bahasa Arab, Bahasa Inggris dan public speaking dalam bentuk khitobah (berpidato), dalam jadwal sekolah Madrasah Diniyah Islam (Madisam), pendidikan karakter dan ketrampilan kewirausahaan. Santri juga diberikan materi pendidikan karakter dan nasionalisme, agar santri memahami kebhinekaan yang ada di Indonesia dan tidak mengatasnamakan agama untuk kepentingan pribadi atau kelompok. Materi kewirausahan diberikan dalam bentuk pelatihan agar santri dapat mandiri secara ekonomi mengembangkan ketrampilannya dalam kehidupan bermasyarakat

c. Modernisasi Metode Pembelajaran.

Selama ini metode bandongan atau halaqoh hanya memberi kesempatan santri mendengarkan, menyimak dan mencatatnya, dan metode sorogan lebih mengharuskan para santri mengikuti dan menirukannya berulang kali materi yang dibaca Kyai, santri diwajibkan menguasai cara membaca dan terjemahannya secara tepat. Kedua metode ini sekarang diimplementasikan dan dipadukan dengan metode takror yaitu : sistem pembelajaran sebaya atau sistem pembelajaran yang dilakukan oleh senior ke juniornya seperti muroja'ah, diskusi, serta musyawarah, dan pendekatan basul masail atau pemecahan masalah, sehingga terjadi interaksi untuk mendekatkan dan memberi pemahaman santri secara luas dan mendalam materi kitab yang dikaitkan dengan peristiwa-peristiwa yang terjadi dalam masyarakat.

Metode lain yang dikembangkan dan diaplikasikan adalah "ngudi kawruh" atau kunjungan belajar ke pondok pesantren lain, antara lain : pondok pesantren Gontor dan Tebu Ireng Jombang, bekerja sama dengan bengkel Sri Rejeki Semarang untuk memberikan pelatihan kewirausahaan kepada santri dalam bentuk praktek kerja di bengkel Sri Rejeki Semarang, pelatihan rebana dan qosidah modern dan bekerjasama dengan Ikatan Pondok Pesantren Indonesia atau IPPI dengan membuat koperasi "Bejo".

d. Modernisasi Sumber Daya Manusia.

Dimaksudkan untuk meningkatkan kualitas para pendidik, ustad/ustadzah dan para pengasuh, yang dilaksanakan dengan memberi kesempatan para pendidik dan pengasuh untuk studi lanjut pada jenjang pendidikan tinggi, kerjasama antar pondok pesantren dengan cara salah satunya adalah pertukaran pengajar atau melaksanakan pengajaran di tempat lain, 
mengikutsertakan pada kegiatan diklat baik yang diselenggarakan Kementerian Agama maupun kerjasama antar pondok pesantren.

e. Modernisasi Sarana dan Prasarana.

Dari hasil observasi diperoleh data ketersediaan bangunan fisik pondok pesantren untuk kamar tidur, kamar mandi, dapur dan masjid, serta fasilitas fisik lainnya untuk tempat tinggal para santri dan para ustad/ustadzah dengan kondisi memadai dan baik. Modernisasi sarana prasarana harus dilaksanakan secara bertahap, mengingat keterbatasan dana yang ada, saat ini baru ada seperangkat LCD yang digunakan secara bergantian oleh para santri. Penambahan meja kursi belajar santri serta sarana prasarana pembelajaran digital komputer, $L C D$ dan sound system menjadi skala prioritas modernisasi sarana prasarana pendidikan di pondok pesantren, utamanya untuk dimanfaatkan dalam pengembangan ketrampilan berpidato/ khitobah dan ceramah. Bekerjasama dengan pendidikan formal SMA dan SMK telah dibangun ruang laboratorium computer yang diisi dengan 10 unit computer. Meskipun masih banyak kekurangan yang terkait dengan pengadangan fasilitas berbasis digital, namun melalui handphone android yang sudah dimiliki para santri, dimanfaatkan untuk meningkatkan kualitas pembelajaran para santri.

\section{Kendala Pelaksanaan Modernisasi Pendidikan Di Pondok Pesantren Miftahul 'Amal}

Dalam wawancara dengan Pengasuh pondok pesantren, disebutkan, "ketika sebuah sistem atau program pondok pesantren modern dijalankan, akan berbenturan dengan sistem lama, dibutuhkan pemahaman para kyai dan tenaga pendidik akan skill dan mentalitas yang tangguh, untuk mendapatkan pengalaman memajukan pesantren modern sesuai perkembangan zaman, dan ketika system berjalan kendala terberat adalah diperlukan dana untuk memenuhi kelengkapan alat-alat yang dibutuhkan dalam proses modernisasi".

Ketua pondok pesantren Ahmad Sholeh, S.Pdi menyebutkan, " kendala utama proses modernisasi pesantren diantaranya SDM ustadz dan ustadzah serta sarana prasarana yang masih kurang"

Modernisasi pendidikan di pondok pesantren pada dasarnya telah dilaksanakan secara bertahap, disesuaikan dengan kondisi dana dan sumber daya manusia yang ada. Pelaksanaan modernisasi pondok pesantren tidaklah mudah, terdapat kendala internal dan eksternal yang dihadapi, antara lain :

a. Kendala internal, diantaranya :

1) Sulitnya merubah mindset para Kyai dan Ustad 'sepuh', baik dalam perubahan kurikulum, metode pembelajaran dan penggunaan teknologi baru. Ada kekhawatiran para Kyai dan Ustad sepuh, perubahan kurikulum dan metode pembelajaran di pondok pesantren akan mengurangi penguasaan ilmu agama para santri, serta penggunaan teknologi modern oleh para santri dikhawatirkan akan memecah konsentrasi santri dan berdampak buruk pada santri yang lebih banyak mengakses konten-konten yang tidak berkaitan dengan ilmu agama.

2) Keterbatasan kualitas sumber daya manusia, beberapa ustad/ustadzah masih berpendidikan setingkat SMA meskipun lulusan pondok pesantren dan telah menguasai kitab-kitab klasik. Untuk meningkatkan kualitas sumber daya manusia, pondok pesantren memberi kesempatan pada para ustad/ustadzah dan para pengasuh yang lain untuk studi lanjut pada jenjang pendidikan formal yang lebih tinggi dan " ngudi kawruh " di pondok pesantren lain yang tergabung dalam IPPI.

3) Keterbatasan dana, diperlukan dana yang cukup besar untuk pembiayaan studi lanjut para pengasuh pondok, membangun fasilitas tambahan serta sarana-prasarana pendidikan berbasis teknologi terbarukan. Oleh karena itu modernisasi dilaksanakan secara bertahap dengan skala prioritas sesuai kebutuhan pondok pesantren. 
b. Kendala eksternal

1) Ilmu dan ketrampilan yang dibutuhkan masyarakat dan harus dikuasai santri semakin kompleks, dibutuhkan penyesuaian kurikulum yang mampu mengakomodasi berbagai ketrampilan baru yang harus dimiliki para santri, agar santri mampu mandiri dan mampu mengimplementasikan penguasaan kitab-kitab klasik secara tepat pada berbagai peristiwa dalam masyarakat.

2) Perkembangan teknologi yang semakin cepat dengan kualitas tinggi dan berbasis daring, membutuhkan jaringan internet dan sarana-prasarana baru, serta keterbatasan penguasaan teknologi para ustad/ustadzah dan pengasuh pondok pesantren, sehingga membutuhkan dana yang cukup tinggi untuk memenuhinya.

\section{SIMPULAN}

Latar belakang dilaksanakannya modernisasi di pondok pesantren Miftaul 'Alam, antara lain : harapan dan kinginan yang kuat dari Pengasuh dan Ketua dan para ustadz/ustadzah pondok pesantren Mitaul 'Alam untuk menghilangkan persepsi masyarakat tentang pendidikan di pesantren kuno, tidak bermutu dan hanya mengajarkan ilmu agama secara konvensional, dan tradisi lama pondok pesantren jika dipertahankan tanpa ada penyesuaian dengan perkembangan ilmu pengetahuan dan teknologi, dan tanpa keiktusertaan para santri berdialog tentang peristiwa kekinian dalam masyarakat, hanya akan menghasilkan santri yang sekedar menerima, menghafal dan meniru ilmu agama yang dipelajarinya dari para kyai.. Hal tersebut akan menyebabkan pondok pesantren yang tidak memodernisasi diri tidak diminati oleh para remaja dan para orang tua yang telah memanfaatkan keterbaruan ilmu dan teknologi dalam kehidupan bermasyarakat .

Tujuan modernisasi pondok pesantren Miftaul 'Alam adalah: meningkatkan kualitas santri lulusan pondok pesantren, yang tidak hanya menguasai ilmu agama dari kitab kuning, tetapi juga mendapatkan bekal pengetahuan, sikap dan ketrampilan yang utuh, baik ilmu agama, ilmu-ilmu pengetahuan lain dan teknologi yang terus berkembang, dan mengikuti pelajarannya dengan metode yang lebih modern, menguasai isi pembelajaran dan life skills-nya, sehingga mampu menerapkan secara comprehensive makna isi kitab kuning terkait dengan peristiwa dan kehidupan masyarakat yang semakin kompleks.

Pelaksanaan modernisasi pondok pesantren Miftaul 'Alam dilaksnakan secara bertahap berdasarkan skala prioritas, meliputi: modernisasi kelembagaan, kurikulum, metode pembelajaran, sumber daya manusia, terutama para pendidik dan pengasuh serta sarana dan prasarana pondok pesantren. Berbagai kendala dihadapi pondok pesanten dalam pelaksanan modernisasi antara lain : kendala internal, kekhawatiran para kyai dan ustadz/ustadz terhadap perkembangan teknologi dan penggunaan gawai akan mengakibatkan menurunnya penguasaan ilmu agama para santri, keterbatasan kualitas SDM dan keterbatasan dana. Kendala ekternal, diantaranya : ilmu dan ketrampilan yang dibutuhkan masyarakat dan harus dimiliki santri semakin berkembang dan kompleks serta kecepatan perkembangan teknologi berbasis daring, yang membutuhkan sarana prasarana baru dan SDM yang kompeten di bidang teknologi.

Eksistensi pondok pesantren Miftaul 'Alam harus dipertahankan dan ditingkatkan, melalui pemahaman internal antara Pengasuh,Ketua, ustadz/ustadzah, orang tua dan para santri akan kebutuhan modernisasi, agar dapat meningkatkan kualitas pendidikan dan berhasil menjadi pondok pesantren modern yang mendapat kepercayaan masyarakat untuk mendidik para santri, tidak saja menjadi ahli agama, namun juga mampu mengimplementasikan keilmuannya dalam membantu masyarakat memecahkan masalah kehidupan yang semakin komplek dengan memanfaatkan teknologi terbarukan. 


\section{DAFTAR PUSTAKA}

Arief, Armai, 2002, Pengantar Ilmu dan Metodologi Pendidikan Islam, Jakarta: Ciputat Press

Aziz, Abdul. 2014. Modernisasi Sistem Pendidikan Pesantren. Skripsi pada UIN Syarif Hidayatullah. Jakarta. Dipublikasikan

Azra, Azyumardi. 2001. Pendidikan Islam, Tradisi dan Modernisasi Menuju Milenium Baru. Jakarta: Kalimah

Dahri, Harapandi. 2007. Modernisasi Pesantren. Jakarta: Balai Penelitian dan Pengembangan Agama

Dhofier, Zamakhsyari. 2011. Tradisi Pesantren. Jakarta: LP3ES

Khoirzaman, 2014, Modernisasi Pendidikan, diakses tanggal. 12 Maret 2019, http://khoirzaman.blogspot.com/2014/12/modernisasi-pendidikan.html

Kompri. 2018. Manajemen dan Kepemimpinan Pondok Pesantren. Jakarta: Prenada Media Group

Mahmud. 2011. Pemikiran Pendidikan Islam. Bandung: Pustaka Setia

Mastuhu. 1994. Dinamika Pendidikan Pesantren. Jakarta: INIS

Mas'ud, Abdurrahman. 2013. Kyai Tanpa Pesantren. Yogyakarta: Gama Media

Mughits, Abdul, 2008, Kritik Nalar Fiqh Pesantren, Jakarta : Prenada Media Group.

Qomar, 2005, Peantren: Dari Transformasi Metodologi Menuju Demokratisasi Institusi.Jakarta: Erlangga.

Saefudin, Furkon. 2016. Modernisasi Pendidikan Pesantren Perspektif Nurcholis Madjid. Skripsi pada UIN Alauddin.Makasar. Dipublikasikan

Soekanto. Soerjano, 2017. Sosiologi Suatu Pengantar. Edisi Revisi, Jakarta: Rajawali Press

Undang-undang Republik Indonesia Nomor 20 tahun 2003 tentang Sistem Pendidikan Nasional

Wahid, Adurrahman. 2001. Menggerakkan Tradisi. Esai-esai Pesantren. Yogyakarta: LKIS Yogyakarta

Yasmadi.2002. Modernisasi Pesantren Kritik Nurcholis Madjid Terhadap Pendidikan Islam Tradisional. Jakarta Selatan: Ciputat Press 